\title{
Depth Analysis of Fatty Acids in Two Caribbean Reef Corals
}

\author{
P.A. Meyers ${ }^{1}$, J.W. Porter ${ }^{2}$ and R.L. Chad ${ }^{1 *}$ \\ ${ }_{1}^{1}$ Department of Atmospheric and Oceenic Science, The University of Michigan; Ann Arbor, Michlgan, USA and \\ ${ }^{2}$ Department of Zoology, University of Georgie; Athens, Georgie, USA
}

\begin{abstract}
Total fatty acld compositions of colonies of two hermatypic, reef-building corals collected during the day-time over a depth range of $21 \mathrm{~m}$ were determined to assess the effect of depth-related environmental factors upon the lipid content of these organisms. No systematlc changes were found, suggesting a steady-state balance between algal and animal l1pogenesis in these symbiotic partnerships. Stephanocoenia michelinii, a day and night feeder, contained liplds 1ndicative of external dietary sources such as copepods, whereas Montastrea annularis, a night feeder, did not.
\end{abstract}

\section{Introduction}

Hermatypic reef corals are characterized by a mutualistic association between host cnldarlans and their dinoflagellate symbionts. A feature of this relationship is the translocation of photosynthetlc products from the algae to their animal parters. Carbon fixed by the algae can appear in the host in a variety of forms. To date, synthesis and movement has been demonstrated for sugars, primarily glucose and glycerol (Muscatine, 1967; Muscatine and Cernichiar1, 1969; Lewis and Smith, 1971; Trench, $1971 \mathrm{a}, \mathrm{b})$; amino ac1ds, for instance alanine or leucine (Muscatine and Cernichlari, 1969; Lewis and Smith, 1971); proteins (Young et al., 1971); chitin (Young et al.,1971); and lipids, primar1ly triglycerides (Muscatine and Cernichiar1, 1969; Young et al., 1971; Patton et al., 1977). Von Holt and Von Holt (1968) demonstrated with the Cartbbean coral scolymia lacera (Pallas) that roughly one-half of all $\mathrm{CO}_{2}$ flxed during photosynthesis and translocated into watersoluble or alcohol-soluble extracts is located in the lipid fraction. This amount fixed into animal lipid represents almost 208 of all the $\mathrm{CO}_{2}$ fixed during photosynthesis. Muscatine and Cernichtari (1969) found that when this

\footnotetext{
*Present address: Department of Blology, University of South Florida, Tampa, Florida 33612 , USA.
}

labeled animal-tissue lipid was deacylated, 14C was detected only in the glycerol molety suggesting animal synthesis of these lipids from simpler components. Recent evidence, however, suggests an algal origin for some lipid synthesis (Patton et al., 1977), and it has been speculated that coral fatty acid compositions are to a large extent controlled by algal blosynthesis, and that much of the fatty acid content of the host antmal is derived unaltered from the zooxanthellae (Meyers, 1977; Patton et al., 1977).

Since fatty acids can be photosynthetically derived, whether as direct products of translocation or indirect products of animal synthesis from algal components, their production might be a function of depth-related changes in light intensity or spectral quality. Other parameters show such trends. For instance, with increasing depth, lightcontrolled, stable carbon isotopic compositions of Caribbean reef corals become progressively 11 ghter in $13 \mathrm{C}$ in both tissues (Land et al., 1975) and in the carbonate skeletons (Weber et al., 1976). Further, colonies of the Pacific coral Pavona praetorta (Dana) from depths of 10 and $25 \mathrm{~m}$ show distinctive oxygen production and consumption rates indicative of phystological adaptations to thetr ind1vidual light regimes (Wethey and porter, $1976 \mathrm{a}, \mathrm{b})$. These photoadaptation patterns reoccur in the Cartbbean coral Montastrea annularis (Ellis and Solander) from 
Jamalca (Davles, 1977; Wethey and Porter, in preparation). This species also shows a close correlation between ambient light conditions and skeletal morphology (Graus and Macintyre, 1976).

In view of these observed depthrelated varlations in coral composition, we were interested in determining if there existed changes in coral fatty acid content with increasing depth. If such changes were found, they might indicate varlations in the dependence of coral on an algal source of coral lipids, and hence an increasing or decreasing dependence on heterotrophlcally derived food over depth ranges of decreasing light supply. Differences in total fatty acid composition might also indicate variations in the amount of translocated photosynthates with depth.

\section{Matorials and Methods}

Coral samples from the seaward edge of the fringing-barrier reef at Discovery Bay, Jamaica, were hand-collected between 10.00 and $13.00 \mathrm{hrs}$ using SCUBA in March, 1976. Small pieces of colonies of two hermatyplc species, Montastrea annularis and stephanocoenia michelinii (M1lneEdwards and Halme), were obtained at depths ranging from 3 to $24 \mathrm{~m}$. $M$. annularis was one of the first scleractinian corals in which the movement of photosynthetically fixed carbon was experimentally demonstrated (Goreau and Goreau, 1960), and, as cited above, has been the object of a variety of physlological studies, many of them belng conducted at Discovery Bay. It is a major frame butlder, with colonies at Discovery Bay occurring from sea level to $80 \mathrm{~m}$ (Goreau and Wells, 1967). It 1s a capable plankton feeder, expanding at night and contracting during the day (Porter, 1974). s. michelinii is similar in many respects in size, overall shape, and depth range on the reef, but differs in position on the substrate and in activity periods. s. michelinii generally grows closer to the substrate, often in the understory layer with numerous branching coral species overtopping it. It too is a capable plankt1vore, but most colonies are expanded fully both day and night instead of just at night. The result of this behavior is that it is probably feeding continuously on ambient plankton supplies.

The samples were frozen immediately at $-20^{\circ} \mathrm{C}$ and remained frozen unt1l analysis was started 1n July 1976. Freezing at $-30^{\circ} \mathrm{C}$ has been shown to be a satisfactory method for preservation of zoo- plankton for lipid analysis for periods up to 9 months (Morris, 1972).

Water temperature was measured at each collection location and was found to be 1sothermal at $26.0^{\circ} \mathrm{C}$ over the entire depth range. Salinity was determined by taking samples of water from each depth back to the laboratory, for measurement with an American Optical company Refractometer Salinometer. A small salinity increase of $2 \%$ was found in the top, $14 \mathrm{~m}$. At depths below this, salinity did not vary from 35\%.

Total fatty aclds in the comblned coral and algal tissue were prepared for analysis by the procedure of Meyers et al. (1974), as modified by Meyers (1977). Extracted fatty aclds were converted to their methyl esters as described by Meyers et al. (1974) using a procedure adapted from that of Metcalfe et al. (1966). Analysis of these esters was by gas-liquid chromatography (Meyers, 1977). Individual components of the total fatty acld composition were identifled by comparison of their retention times to those of authentic standards. Replicate analyses yielded coefflclents of varlation of less than 38 .

\section{Results}

Fatty acid compositions for the 9 individual tissue samples of Hontastrea annularis from various depths are listed in Table 1. Single samples from 4 entirely separate colonies of $M$. annularis were collected at $9 \mathrm{~m}$ in order to assess var1abllity between colonies of this species from one depth. The most abundant component in the composition of these 4 replicate samples from $9 \mathrm{~m}$ is palmitic acid $(16: 0)$ with a mean weight percent of 618 and a coefficient of vartation of 11.38 of the mean. The second-most abundant fatty acid is oleic $(18: 1)$. Its mean contribution is 11.78 in these 4 samples, and 1 ts coefficient of variation is 15.08 of the mean. The other major acids, defined as contributing 18 or more to the total composition, show considerable varlablity. The data from these 4 samples support the findings of Meyers et al. (in preparation) from analysis of 8 replicate samples of Manicina areolata (LInnaeus). Actds comprising $20 \%$ or more of the total composition have considerably less variability than lesser components, and such acids may be useful in comparative studies of the type reported here.

No systematic change with depth of collection was observed in the total fatty acid composition of the samples of Montastrea annularis analyzed in this study. Furthermore, there appeared to be no s1g- 
Table 1. Montastrea annularis. Fatty acid weight percent compositions of colonies from varlous depths

\begin{tabular}{lrrrrrrrrr}
\hline Major acid & Depth $(\mathrm{m})$ & & & & & & \\
& \multicolumn{1}{c}{3} & 6 & 9 & 9 & 9 & 9 & 12 & 18 & 24 \\
\hline Myristic $(14: 0)$ & 2.5 & 3.8 & 1.0 & 0.8 & 2.4 & 1.6 & 2.5 & 0.9 & 1.8 \\
Palmitic $(16: 0)$ & 65.4 & 62.5 & 59.6 & 52.0 & 64.5 & 67.8 & 66.4 & 72.3 & 70.3 \\
Palmitoleic (16:1) & 4.2 & 5.1 & 4.3 & 0 & 0.9 & 2.8 & 4.8 & 2.6 & 0 \\
Stearic (18:0) & 12.2 & 8.2 & 2.7 & 18.5 & 5.5 & 6.6 & 9.4 & 12.1 & 18.8 \\
Ole1c (18:1) & 8.8 & 12.4 & 11.6 & 12.5 & 9.3 & 13.4 & 10.3 & 7.8 & 7.0 \\
Linoleic (18:2) & 1.1 & 1.6 & 2.5 & 0.3 & 3.1 & 1.9 & 1.1 & 0.6 & 0.6 \\
Arachidic (20:0) & 0.1 & 0.5 & 0 & 0.5 & 0 & 0 & 0.5 & 1.0 & 0 \\
Elcosenotc (20:1) & 0.1 & 0 & 0 & 2.4 & 0 & 0 & 2.0 & 2.8 & 1.5 \\
Docosahexaenolc (22:6) & 0 & 2.2 & 2.6 & 0 & 3.1 & 0 & 0 & 0 & 0 \\
\hline
\end{tabular}

Table 2. Stephanocoenia michelinii. Fatty acid weight percent compositions of colontes from vartous depths

\begin{tabular}{|c|c|c|c|c|c|c|c|}
\hline \multirow[t]{2}{*}{ Major acid } & \multicolumn{7}{|c|}{ Depth (m) } \\
\hline & 3 & 6 & 9 & 12 & 14 & 18 & 24 \\
\hline Myristic (14:0) & 0.3 & 1.9 & 0.6 & 2.6 & 1.0 & 1.5 & 1.0 \\
\hline Palmitic $(16: 0)$ & 6.9 & 43.2 & 54.9 & 68.3 & 29.3 & 50.7 & 52.6 \\
\hline Palmitoleic (16:1) & 0.5 & 3.0 & O & 2.9 & 1.8 & 2.1 & 2.1 \\
\hline Steartc $(18: 0)$ & 2.6 & 9.7 & 19.1 & 11.6 & 7.6 & 13.9 & 15.3 \\
\hline Oletc $(18: 1)$ & 2.1 & 7.8 & 15.3 & 8.4 & 18.9 & 17.4 & 15.8 \\
\hline Linoletc $(18: 2)$ & 0.4 & 2.5 & 1.1 & 2.1 & 1.5 & 3.0 & 1.9 \\
\hline Arachidic $(20: 0)$ & 0.6 & 3.7 & 4.4 & 2.0 & 2.0 & 5.4 & 4.5 \\
\hline Eicosenoic $(20: 1)$ & 0.5 & $\mathrm{O}$ & 4.8 & 2.1 & 5.9 & 5.9 & 4.0 \\
\hline Docosahexaenotc $(22: 6)$ & 82.8 & 16.4 & 0 & o & 15.0 & 0 & 0 \\
\hline
\end{tabular}

nificant difference between the shallowest and the deepest samples. The mean palmitic acid composition of samples from all depths is 64.58 , with a coefficient of variation of 9.58 . This is essentially the same as the 4 replicate samples from $9 \mathrm{~m}$. Similarly, olelc acld has a mean composttion of 10.38 of the mean. Other minor components are more variable, both within depths as well as between depths.

Fatty acid compositions of the 7 samples of Stephanocoenia michelinii in Table 2 show more variability than those of Montastrea annularis, but also show only minor, non-significant depth-related trends. Palmitic acid is again the major fatty acid in most of the samples, and averages 448 of the total acids versus 64.58 for $M$. annularis. However, the shallowest sample contains a low percentage of this acid. Its composition is dominated

(82.88) Instead by the marine-type, polyunsaturated docosahexaenolc acld (22:6), which also appears in sizeable amounts in the samples of this species collected from depths of 6 and $14 \mathrm{~m}$ but not from any of the other depths. Th1s acid is present in some of the $M$. annularis samples only as a minor component $(<3.18)$.
The low level of polyunsaturated fatty acids in most of these samples agrees with other reports of low levels or absence of such acids in stoney corals (Pasby, 1965; Meyers et a1., 1974; Patton et al., 1977). However, some corals have been found to contain relatively large amounts of polyunsaturation (Meyers, 1977; Sassen, 1977). It is possible that some loss of polyunsaturated aclds may have occurred during destccation of the coral tissues or during thin-layer chromatography (TLC) isolation of fatty acid methyl esters. N1chaman et al. (1963) have observed losses of polyunsaturated acids during TLC visualization by iodine vapors, and Schultz and Quinn (1977) have determined that 198 of the 22:6 fatty acid can be lost by this method. Although lodine was the visualizing agent In the present study, exposure to vapors was kept brief to minimize loss of polyunsaturated components. Furthermore, the overall procedure used here has been able to detect substantial amounts of polyunsaturated acids and hydrocarbons In a previous study (Meyers, 1977). Therefore, while some losses may have been encountered, it is not likely that they would have been complete, and the 
low level of polyunsaturated acids found in these samples is probably real.

Because docosahexaenolc actd has been previously detected in substantial amounts in only 8 out of 28 coral specles studied, not 1ncluding stephanocoenia michelinii (Meyers, 1977), we were curtous to see the effect of omitting this acid from our tabulated data. When the compositions of $s$. michelinii in Table 2 were recalculated without docosahexaenoic acid, the coefficients of varlation of palmitic, stearlc (18:0), and oleic acids were reduced by half. This 1 mplies that these three acids may comprise the bulk of the coral fatty acld composition, whereas docosahexaenolc acld may be a dietary component still in the process of being digested, or that the presence of this acid is due to some other speclal circumstances.

\section{Discusion}

It is interesting that no systematic depth trend was found in these determinations of total fatty acids in corals. Weber et al. (1976) found Important depthrelated variations in stable carbon 1sotope ratios to occur in skeletal carbonate of Montastrea annularis samples from $\mathrm{St}$. Crolx, U.S. Virgin Islands. These changes resulted in a steady decrease in $13 \mathrm{C}$ content from surface samples to samples collected at a depth of $18 \mathrm{~m}$. Between 19 and $22 \mathrm{~m}$, a discontinulty in the $13 \mathrm{C}: 12_{\mathrm{C}}$ ratio was found which was associated with morphological changes in M. annularis skeleton that also occur at this depth. In contrast, our fatty acid data from this same species show no differences over this critical depth range. This can be interpreted to mean that skeletal morphology has no facile correlation with the total fatty acid composition of hermatypic coral tissue.

However, analysis of $13 \mathrm{C}: 12 \mathrm{C}$ ratios in whole tissues of Montastrea annularis and of separated extracts of 1 ts endosymblotic algae by Land et al. (1975) showed that, while both total tissue and algal isotope ratios were very similar, no depth-related changes occurred above $40 \mathrm{~m}$ in samples from the same Jamalcan site we sampled. The amount of $13 \mathrm{C}$ in tissues decreased in deeper samples, similar to skeletal $13 \mathrm{C}$, but not until a depth of $40 \mathrm{~m}$ was reached and exceeded. Therefore, 1t. is possible that changes in fatty acid composition should not be expected until samples from greater

depths than the $24 \mathrm{~m}$ reached in our collection are analyzed.

One of the objectives of this study was to determine if depth-related changes in translocated lipids could be determined. It is known that lipid materials such as glycerol (Muscatine, 1967; Muscatine and Cernichiari, 1969; Young et al., 1971) and fatty acids (Patton et al., 1977) are transferred from zooxanthellae to thelr hosts. It is further speculated (Patton ot al., 1977) that fatty acids contributed by zooxantheliae are incorporated largely intact into the host-animal tissue. Because of distinctive differences between animal and plant fatty aclds (Gunstone, 1967), the total fatty composition of the algalantmal association should show depthrelated changes. These could be the result of a decrease in the amount of algal biomass relative to animal material or due to a reduction in algal lipogenesis. Both of these possibilities could accompany the reduced light levels encountered with increasing depth. Either possibility would cause a depth-related shift to decreasing amounts of algallike saturated fatty acids and a relative increase in amounts of animal-like polyunsaturated acids.

However, fatty acld compositions of Montastrea annularis in Table 1 are not affected by depth between 3 and $24 \mathrm{~m}$. Therefore, $1 \mathrm{t}$ must be assumed elther that coral metabolism is in fine balance with algal photosynthetic rates and thus decreases with depth, or that the coral animal is altering translocated lipids for 1 ts own use. Both these assumptions have interesting implications. The first implies that coral metabolic rates are related to depth. Indirect evidence exists to support this possibility. Davies (1977) found that oxygen consumption rates per unit area of tissue in samples of $M$. annularis from $40 \mathrm{~m}$ at Discovery Bay, Jamaica, were half those in samples from $2 \mathrm{~m}$. Therefore, it is posstble that metabolism and tissue growth rate also decrease with depth. The second assumption implies that fatty acids synthesized de novo or transformed from algal liplds by the coral animal are predominantly saturated, plant-like materials. This means that coral animals have exceptional lipogenesis schemes because most marine animals are characterized by polyunsaturated liplds (Youngken and Sh1mizu, 1975).

Three of the stephanocoenta michelinii samples in Table 2 contained substantial amounts of the marine-type polyunsaturated docosahexaenolc acid. This acid is found in large percentages in many marine antmals, tncluding copepods (Jeffrles, 1970; Morr1s, 1971). It 1s possible that these samples may have compositions which give chemical evidence of the1r last prey. As stated, the samples 
were collected between 10.00 and 13.00 hrs, a time period when Montastrea annularis does not typically feed but $s$. michelinii does. Along this depth transect in D1scovery Bay, copepods constitute over 908 of the planktonic individuals available for capture both day and night (Porter, $1 \mathrm{n}$ preparation). These prey are digested in less than $3 \mathrm{~h}$ (Porter, 1974), but assimilation rates for the products of digestion are not known. It seems unlikely that recent prey items could account for the high percentage composition of the 22:6 fatty acid (nearly 838). and 1 t seems necessary to postulate some means of accumulation or manufacture to account for so large an amount. It is possible that the presence of substantial amounts of this polyunsaturated acld in the tissues of $S$. michelinit is due to partial alteration of dietary lipids and accumulation of these products as well as recent evidence of diet. If this is true, then corals that actively feed both night and day should have lipid compositions which are more related to those of their prey than corals which feed only at night.

Acknowledgements. This research was supported by a grant from the Scott Turner Memorial Fund of The Univergity of M1chigan to P.A. Meyers, and National Science Foundation Grant OCE7726781 to J.W. Porter. Contribution No, 251 of the Department of Atmosphertc and oceanic Science, and No. 168 of the Discovery Bay Marine Laboratory, University of the West Indes.

\section{Literature Cited}

Davies, P.S.: Carbon budgets and vertical zonation of Atlantic reef corals. Proc. 1nt. Symp. coral Reefs 1, 391-396 (1977). (Th1rd, Ed. by D.L. Taylor. Mlami: University of Mlami)

Goreau, T.F. and N.I. Goreau: D1stribution of labeled carbon in reef-building corals with and without zooxanthellae. Science, N.Y. 131, 668-669 (1960)

- and J.W. Wells: The shallow-water Scleractinla and their vertical distribution range. Bull. mar. Sc1. 17, 442-453 (1967)

Graus, R.R. and I.G. Macintyre: Light control of growth form in colonial reef corals: computer sjmulation. Sclence, N.Y. 193, 895-897 (1976)

Gunstone, F.D.: An introduction to the chemistry and blochemistry of fatty acids and their triglycerides, 2nd ed. 209 pp. London: Chapman \& Eall Ita. 1967

Jeffries, H.P.: Seasonal composition of temperate plankton communities: fatty ac1ds. Limnol. oceanogr. 15, 419-426 (1970)

Land, L.S., J.C. Lang and B.N. Smlth: Preldm1nary observations on the carbon isotopic composttion of some reef coral tissues and sym- biotic zooxanthellae. Limnol. Oceanogr. 20, 283-287 (1975)

Lewis, D.H. and D.C. Smith: The autotrophlc nutrition of symblotic marine coelenterates with special reference to hermatypic corals. $I$. Movement of photosynthetic products between the symblonts. Proc. R. Soc. (Ser. B) $178,111-129$ (1971)

Metcalfe, L.D., A.A. Schmitz and J.R. Pelka: Rapld preparation of fatty acld esters from 11pids for gas chromatographic analysis. Analyt. Chem. 38, 514-515 (1966)

Meyers, P.A.: Fatty acids and hydrocarbons of Caribbean corals. Proc. int. Symp. coral Reefs 1, 529-539 (1977). (Third; Ed. by D.L. Taylor. Miami: University of Miami)

-, J.G. Quinn and N. Marshall: A method for the analysis of fatty acids in coral. Limnol. Oceanogr. 19, 846-848 (1974)

Morris, R.J.: Coraparison of the composition of oceanic copepods from different depths. Comp. Blochem. Phys1o1. 4OB, 275-281 (1971)

- The preservation of some oceanic animais for Itpld analysis. J. Fish. Res. Bd Can. 29, 1303-1307 (1972)

Muscatine, L.: Glycerol excretion by symblotic algae from corals and Tridacna and its control by the host. Science, N.Y. 156, 516-519 (1967)

- and E. Cernichlari: Assimilation of photosynthetic products of zooxanthellae by a reef coral. Blol. Bull. mar. biol. Lab., Woods Hole 137, 506-523 (1969)

Nichaman, M.z., C.C. Sweeley, N.M. Oldham and R. E. Olson: Changes in the fatty acid composition during preparat1ve thin-layer chromatography. J. Lipld Res. 4, 484-485 (1963)

Pasby, B.F.: A characterization of the lipids of the organisms which make up the maln bulk of a coral reef with main emphasis on the hydrocarbons, 149 pp. Ph.D. thes1s, Texas A\&M University 1965

Patton, J.S., S. Abraham and A.A. Benson: Lipogenesis in the intact coral Poctllopora capitata and its isolated zooxanthellae: evidence for a light-driven carbon cycle between symbiont and host. Mar. Blol. 44, 235-247 (1977)

Porter, J.W.: Zooplankton feeding by the Caribbean reef-bullaing coral Montastrea cavernosa. Proc. int. Symp. coral Reefs 1, 111-125 (1974). (Second; Brisbane: Great Barrler Reef Committee)

Sassen, R.: The fate of fatty acids from corals and mangroves in Eolocene seajments of $\mathrm{St}$. Crolx: significance with respect to petroleum genesis. Proc. int. Symp. coral Reefs 2, 135141 (1977). (Third; Ed. by D.L. Taylor. M1ami: Untversity of Miami)

Schultz, D.M. and J.G. Qulns: Note on the chromatographic analyses of marine polyunsaturated fatty acids. Mar. Blol. 40, 117-120 (1977)

Trench, R.K.: The physlology and biochemistry of zooxanthellae symbiotic with marine coelenterates. I. Assimilation of photosynthetic products of zooxanthellae by two marine 
coelenterates. Proc. R. Soc. (Ser. B) 177, 225-235 (1971a)

- The physiology and blochemistry of zooxanthellae symbiotic with marine coelenterates. II. Liberation of fixed ${ }^{14} \mathrm{C}$ by zooxanthellae in vitro. Proc. R. Soc. (Ser. B) 177, 236-250 (1971b)

Von Holt, $C$. and $M$. Von Holt: Transfer of photosynthetic products from zooxanthellae to $\mathrm{CO}-$ elenterate hosts. Comp. Blochem. Physiol. 24, 73-81 (1968)

Young, S.D., J.D. O'Conner, and I. Muscat1ne: organic material from scleractinian coral skeletons. II. Incorporation of ${ }^{14} \mathrm{C}$ into proteln, chitin, and lipld. Comp. Biochem. Physiol. 4OB, 945-958 (1971)

Youngken, H.W. and Y. Shimfzu: Marlne drugs: chemical and pharmacological aspects. In: Chemical oceanography, 2nd ed., Vol. 4. pp 269-317. Ed. by J.P. Riley and G. Skirrow. London: Academic Press 1975

Weber, J.N., P. Detnes, P.H. Weber and P.A. Baker: Depth related changes in the $13 \mathrm{C} / 12_{\mathrm{C}}$ ratio of skeletal carbonate deposited by the Cartbbean reef-frame bullding coral Montastrea annularis: further implications of a model for stable isotope fractionation by sceleractinian corals. Geochim. cosmochim. Acta 40, 31-39 (1976)

Wethey, D.S. and J.W. Porter: Sun and shade differences in productivity of reef corals. Nature, Lond. 262, 281-282 (1976a)

- Habltat-related patterns of productivity of the follaceous reef coral, Pavona praetorta Dana. In: Coelenterate ecology and behavior, pp 59-66. Ed. by G.O. Mackle. New York: Plenum Publishing Corp. 1976b

Dr. Philip A. Meyers

Department of Atmospheric and Oceanic Science The University of Michigan 2455 Hayward Avenue Ann Arbor, Michigan 48109 USA

Date of final manuscript acceptance: June 30, 1978. Communicated by M.R. Tripp, Newark 